\title{
Insects as an Alternative Protein Source for Animal Feeding: A Short Review about Chemical Composition
}

\author{
Vladimír VRABEC ${ }^{1 *}$, Martin KULMA ${ }^{1}$ and Daniel COCAN ${ }^{2}$ \\ 1)Department of Zoology and Fisheries. University of Life Sciences in Prague. Kamýcká 129, 15621 \\ Praha 6 - Suchdol, Czech Republic. \\ ${ }^{2)}$ University of Agricultural Science and Veterinary Medicine Cluj-Napoca, Department of Fundamental \\ Sciences and Biotechnologies, Manastur Str., Nr. 3-5, Cluj-Napoca, 400372, Cluj, Romania \\ *Corresponding author, e-mail: vrabec@af.czu.cz
}

Bulletin UASVM Animal Science and Biotechnologies 72(2) / 2015

Print ISSN 1843-5262; Electronic ISSN 1843-536X

DOI:10.15835/buasvmcn-asb:11656

\begin{abstract}
Currently, insects are considered as a potential substitute for fishmeal and soybean meal in feeding mixtures for farm animals. However, detailed information regarding insects' nutritional values is available only for some species. We suggested criteria for insect suitability to mass production and found 15 species from 5 orders which meet our requirements: Blattaria: Blaptica dubia, Blatta lateralis, Eublaberus distanti, Coleoptera: Alphitobius diaperinus, Tenebrio molitor, Zophobas morio, Diptera: Hermetia illucens, Musca domestica, Lepidoptera: Antheraea assamensis, Bombyx mori, Galleria mellonela, Samia riciini, Orthoptera: Acheta domestica, Locusta migratoria, Zonocerus variegates. We have collected available information about their nutritional composition and compared it to soybean meal and fishmeal. Protein content was found to be similar to (or slightly higher than in) soybean and fish meals. In terms of protein quality, it was found that insect protein composition is more similar to soybean protein or fishmeal with low protein concentration, than to that of high concentration fishmeal or casein. Due to highest lysine and metionin contents, we recommend Musca domestica and Samia riciini as most suitable protein sources for poultry and pigs feeding.
\end{abstract}

Keywords: alternative protein source, amino acid, insects, nutrient content.

Abbreviations: DM - dry matter, CP - crude protein, CF - crude fat, NFE - nitrogen free extracts, ADF - acid detergent fiber, NDF - neutral detergent fiber, $\mathrm{BE}$ - gross energy

\section{INTRODUCTION}

The world population is constantly increasing and human eating habits are globally changing as well. Therefore, sufficient production of meat represents a serious challenge for the future. In regard to production optimisation, it is necessary to provide sufficient quantities of quality feed to unlock maximal genetic potential of animals.

All monogastric livestock (and fish in aquaculture as well) need high quality protein.
Since November 2000, meat bone meals can no longer be used in diets of animals for human consumption (Deydier et al., 2005). Because of this fact, soybean meal and fishmeal are now the most widely used protein sources in animal feeding. Unfortunately, obtaining both of the above mentioned meals leads to local environmental degradation. It is therefore essential to find alternative protein sources.

Insects are currently, considered to possibly be one of such sources, mainly due to their high protein content, cultivation on industry byproducts and organic waste, high feed conversion, high fecundity and low space requirements in the rearing process (Rumpold and Schlütter, 2013). 
Several papers and summaries, dealing with this issue, have recently been published (for all, see Makkar et al. 2014, Sánchez-Muñoz et al. 2014). Both of these reviews consider insects as future food source and discuss pros and cons of the prospect. They also contain detailed information about their nutritional composition. However, the first review only focuses on four most common orders of insects used as food.

The other study is more thorough and provides a comprehensive list of 150 commercially available insect species, and also provides nutritional values of several dozen insect taxa. Although Sánchez-Muñoz et al. (2014) report nutrient composition of a wide range of species, only a minority of them are commercially available in the required quantity (or only for a few is there a known methodology of controlled mass production).

The other reported species were obtained in different ways, such as collection from nature, etc., which means that they could not be used as standardised food for animals. It is also appropriate to point out that the nutritional composition of the most common insect species (used for this purpose) is available in several papers, but there are significant differences between reported results.

The aim of our study was to find out which easily cultivable insect species could be used as a full-fledged replacement for the most common protein sources used for animal feeding (fishmeal and soybean meal).

\section{MATERIALS AND METHODS}

In this review, we focused on insect species which could be considered as a possible future protein source for farm animals. We have gathered available information not only about quantity of basic nutrient content (DM, crude protein, crude fat, chitin, NFE, ADF, NDF, Ca/P ratio, $\mathrm{BE}$ ), but also about the quality of proteins (amino acid composition) and lipids (fatty acid composition).

1. The selection of the insects was based on the following criteria:

2. The species must be commercially available and could be ordered or purchased from specialised mass production companies;
3. The species is bred and produced in multiple countries, and/or the breeding technology is more or less known and publicly available;

4. The species is used as a food source for animals (including companion animals);

5. The information about nutritional composition of the species is available from at least two sources;

6. Papers mentioning the nutritional value of the species have been published during the last ten years.

The information collected about the chemical composition of insect species which meet the required criteria has been put into tables. For species evaluated by several authors, we compiled tables with arithmetic means of avaiable values. NFE negative values (reported by one of the sources) were excluded from arithmetic means calculations. The $\mathrm{g} / \mathrm{kg}$ units were used intentionally in all the tables (only the fatty acids contents are shown in g/100 g). Knowledge about dry matter quantity enables us to more easily assess the quality of insect meal. For comparison, we also added average composition of soybean meal, fishmeal (Banaszkiewicz, 2011; Heuzé et al., 2015a,b), and milk protein (Young and Pellet, 1991).

\section{RESULTS AND DISCUSSION}

Based on the aforementioned criteria, we found 15 species from 5 orders which meet our requirements. We list them in an alphabetical order according to the orders and species: Blattaria: Blaptica dubia (Serville, 1838), Blatta lateralis (Walker, 1868), Eublaberus distanti (Kirby, 1903), Coleoptera: Alphitobius diaperinus (Panzer, 1797), Tenebrio molitor (Linnaeus, 1758), Zophobas morio (Fabricius, 1776), Diptera: Hermetia illucens (Linnaeus, 1758), Musca domestica (Linnaeus, 1758), Lepidoptera: Antheraea assamensis (Helfer, 1837), Bombyx mori (Linnaeus, 1758), Galleria mellonela (Linnaeus, 1758), Samia riciini (Anderson, 1788), Orthoptera: Acheta domestica (Linnaeus, 1758), Locusta migratoria (Linnaeus, 1758), Zonocerus variegates (Linnaeus, 1758).

The information about the nutritional value of these species is shown in Tables 1-3. The average values are displayed in Tables 4 and 5 .

According to our findings, the protein content of most of the reviewed insect species is 


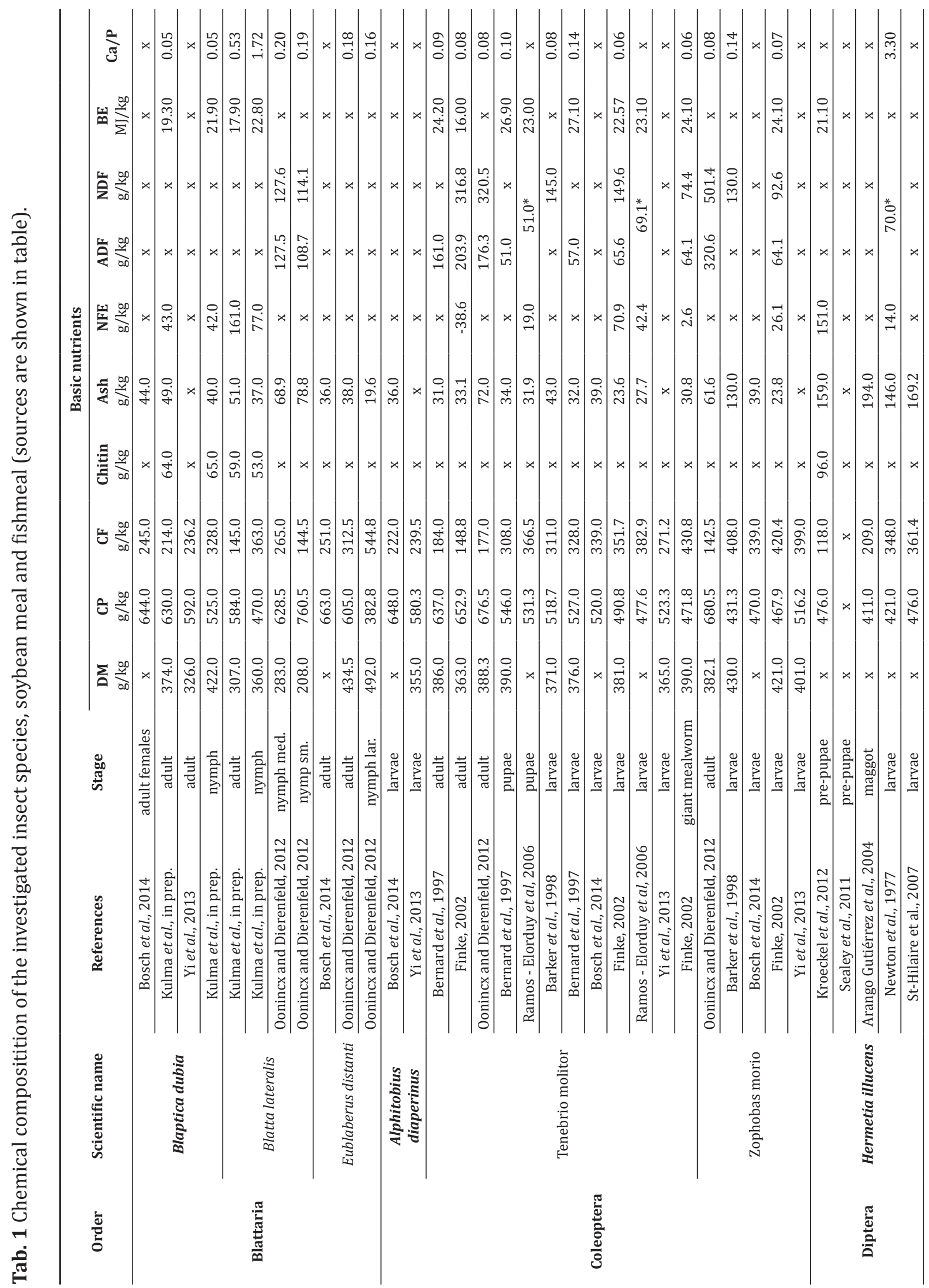




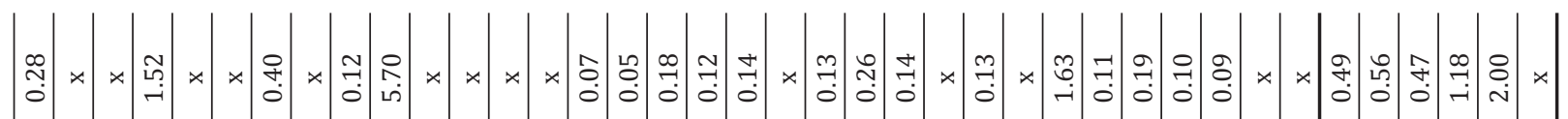

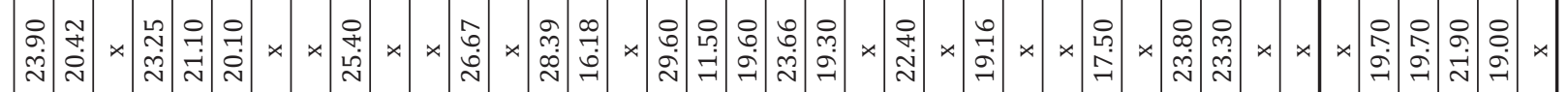

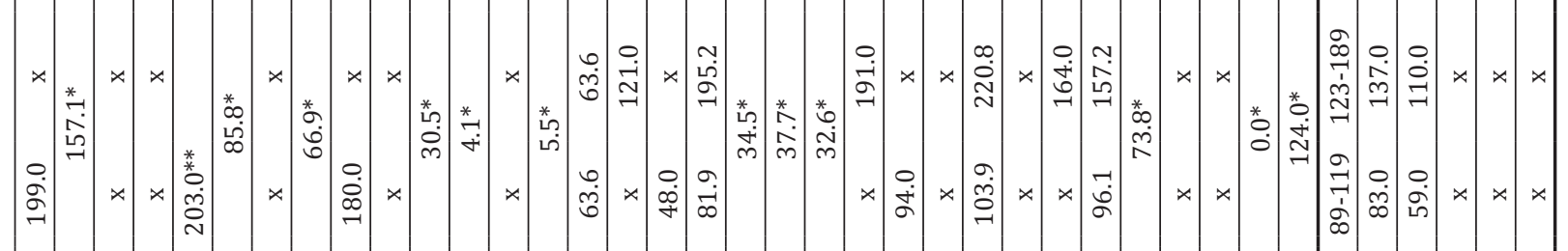

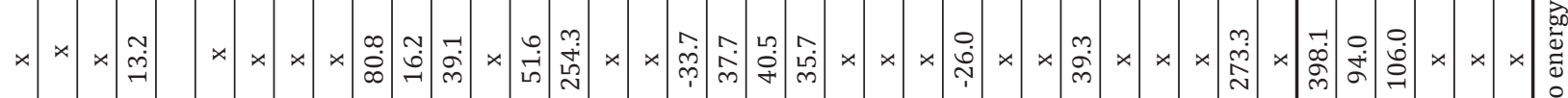

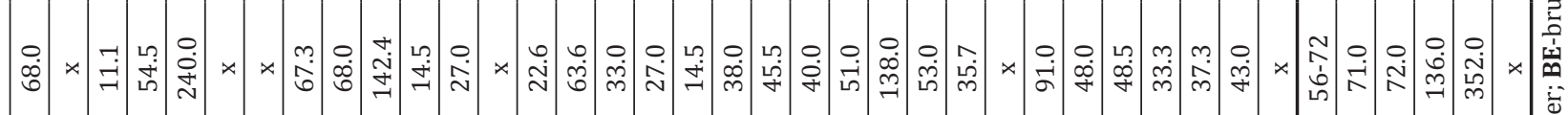

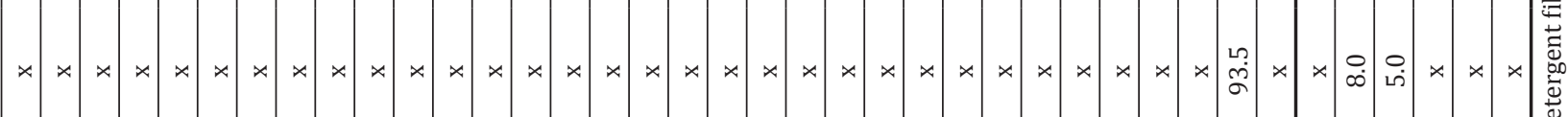

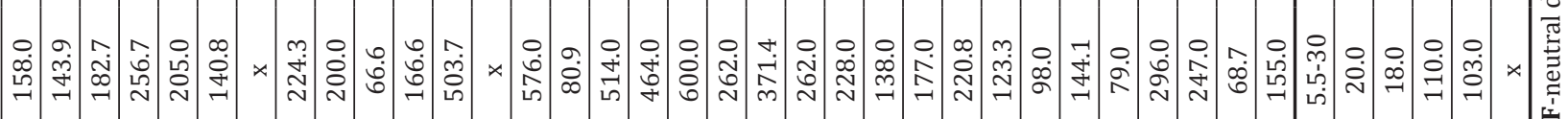

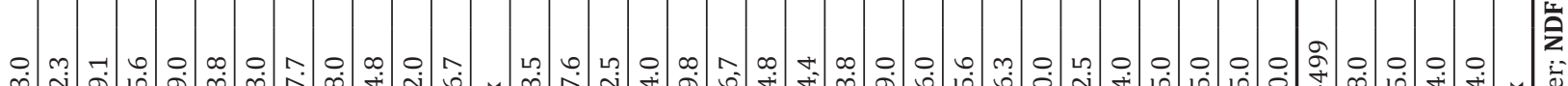

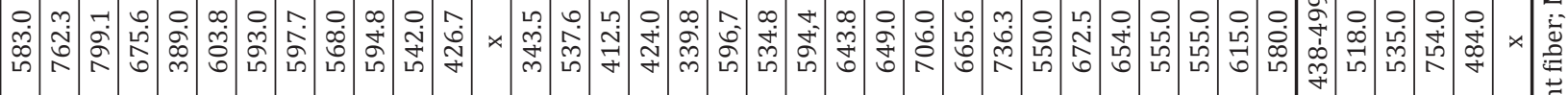

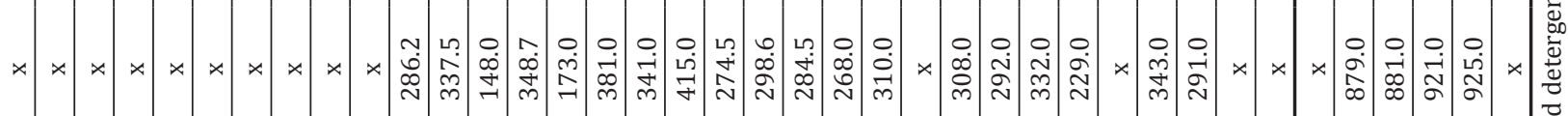

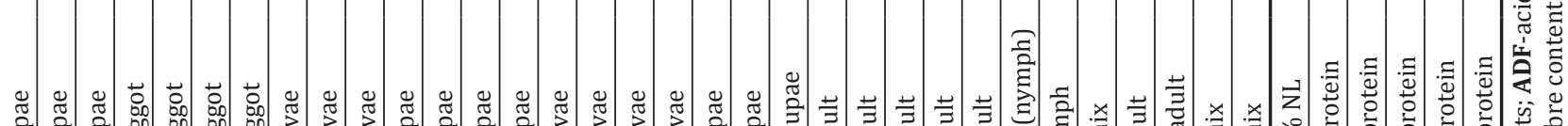

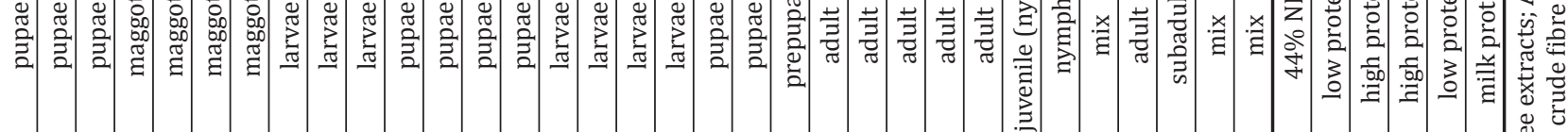

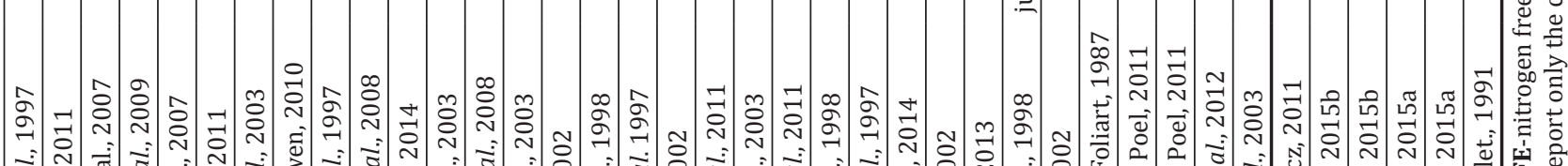

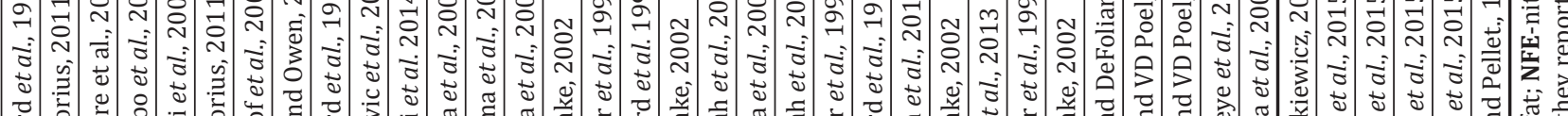

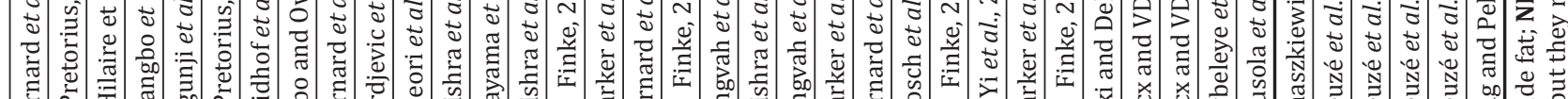

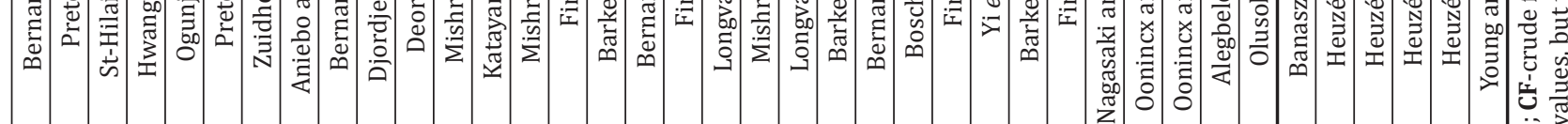

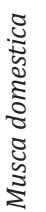

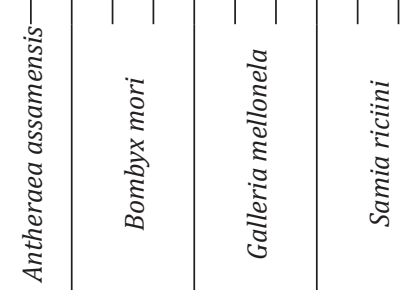

$\frac{0}{\frac{0}{2}}$
营

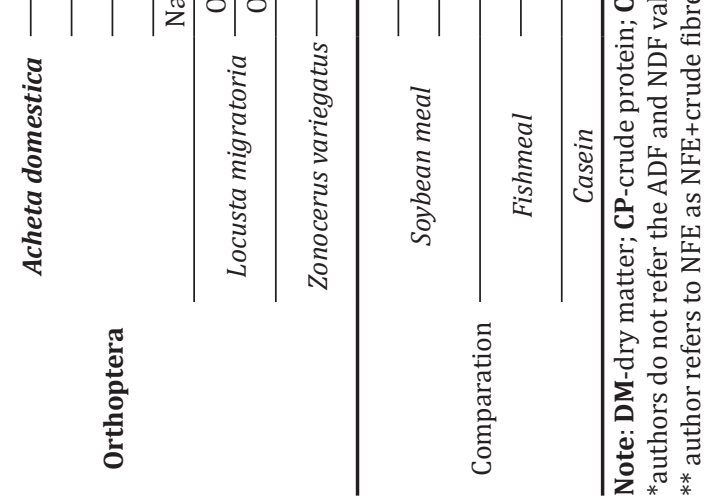




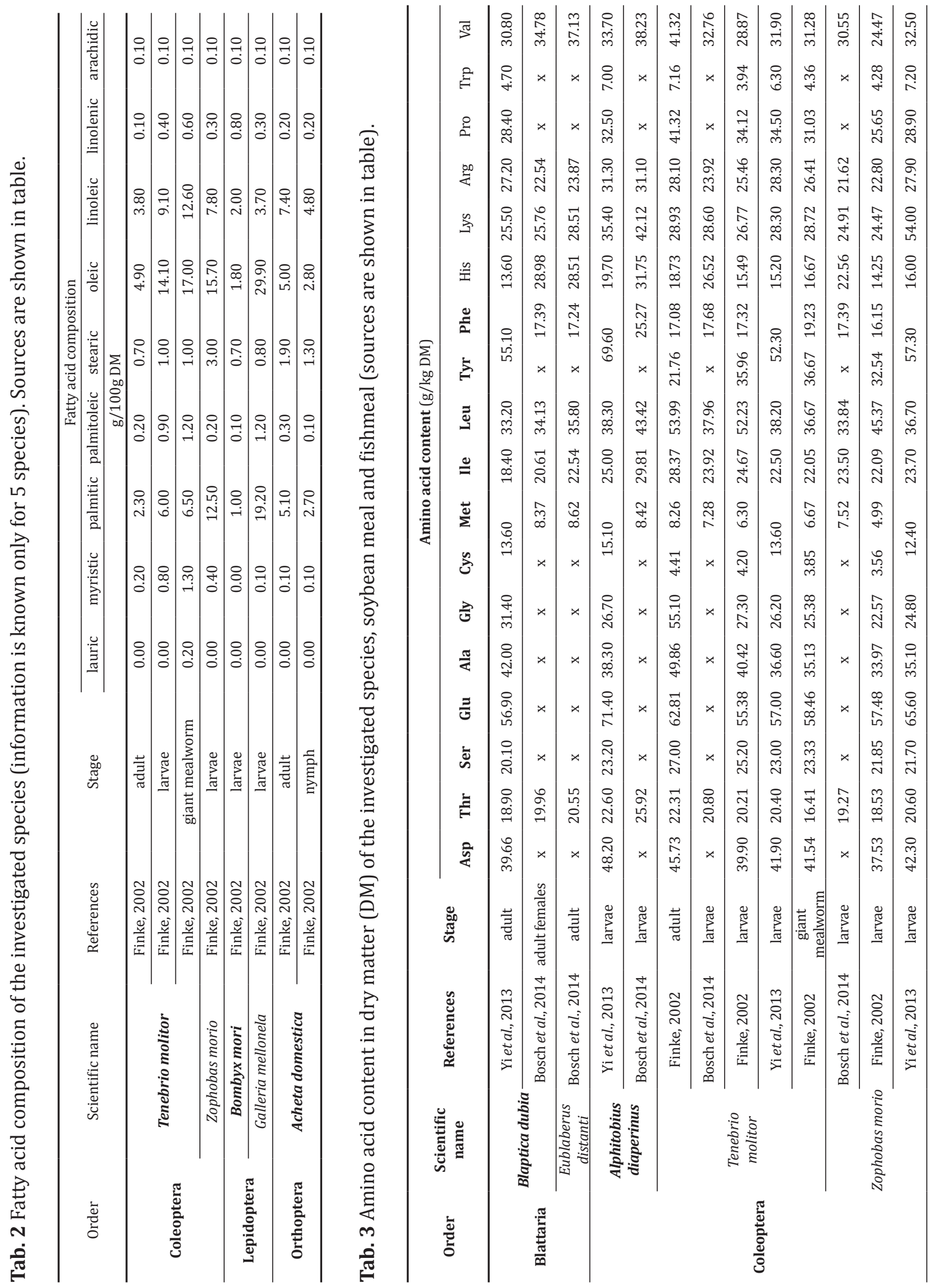




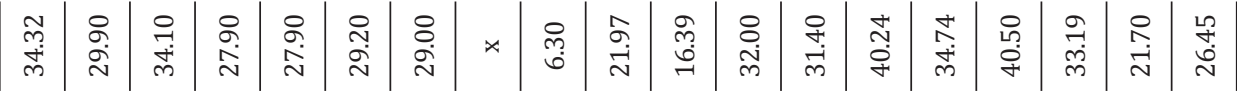

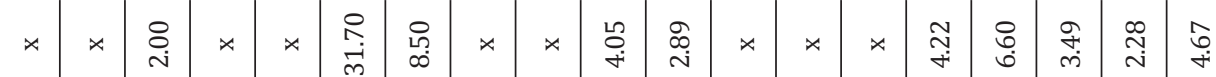

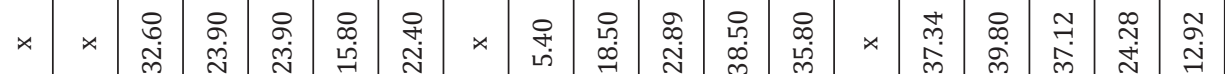

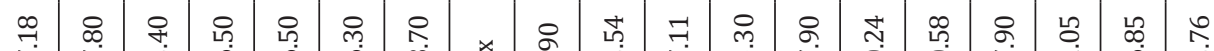

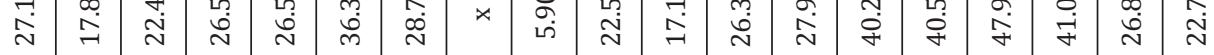

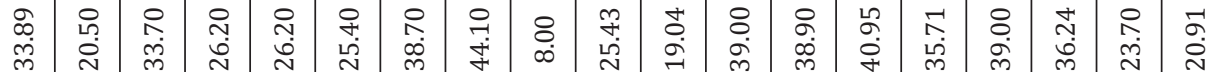

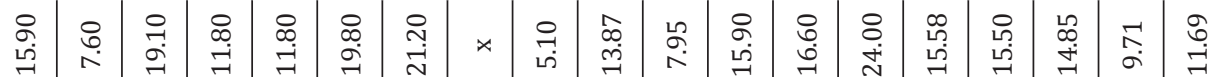

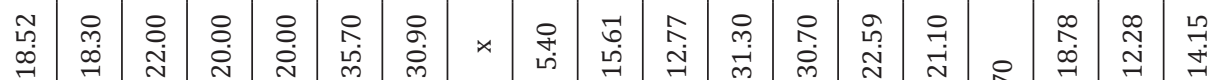

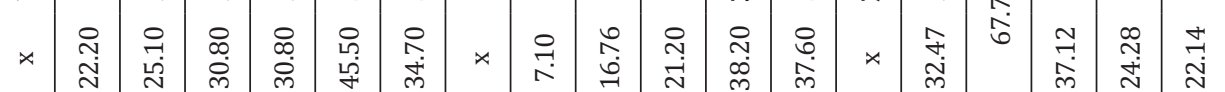

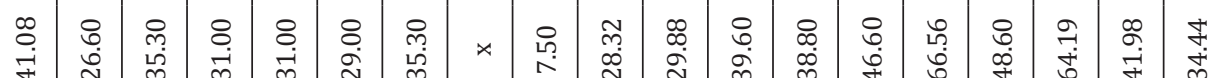

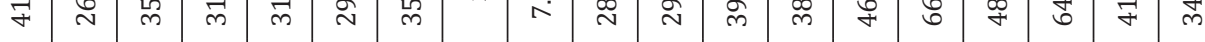

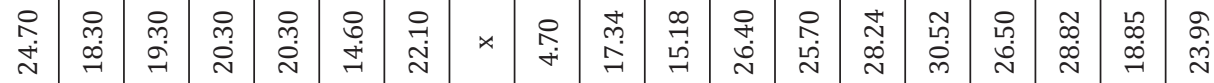

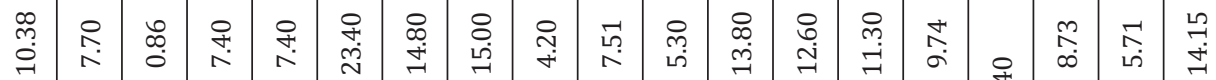

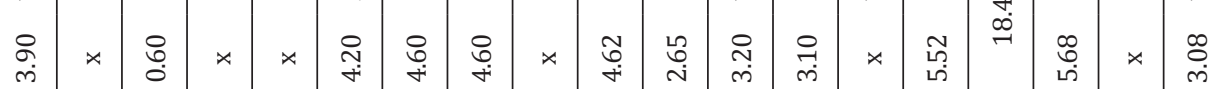

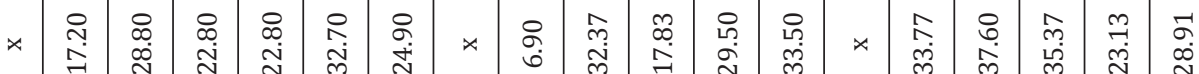

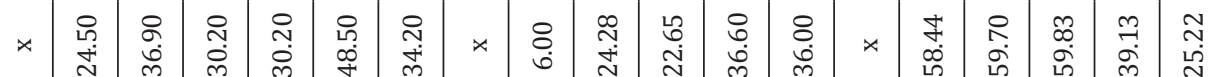

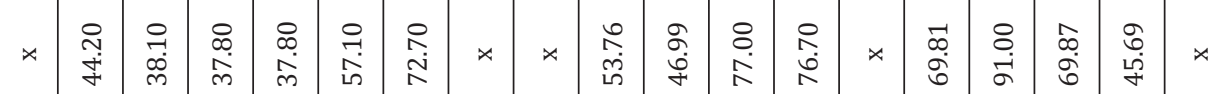

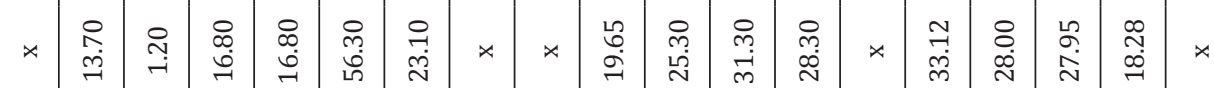

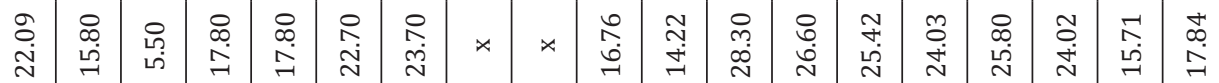

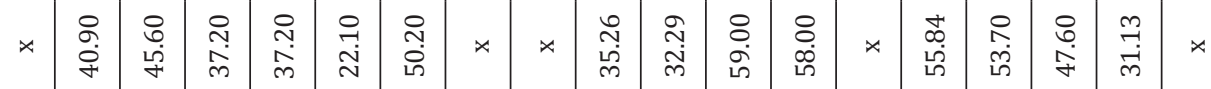

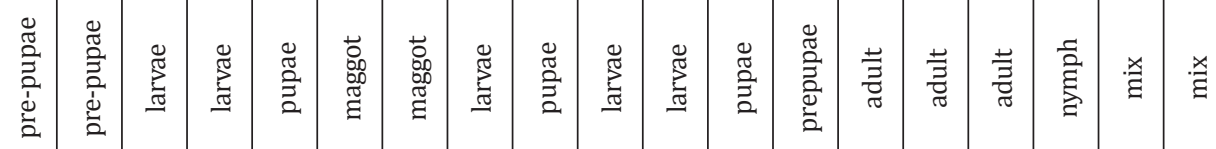

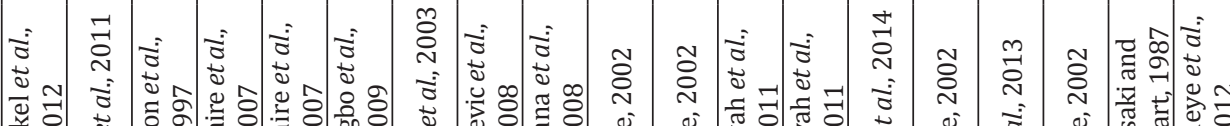

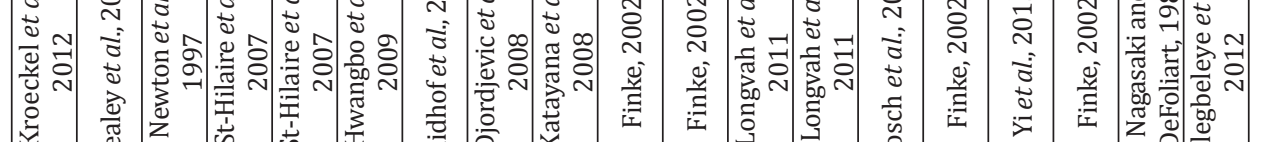
产
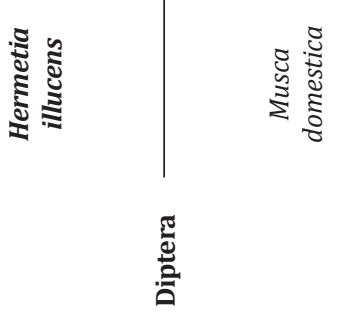

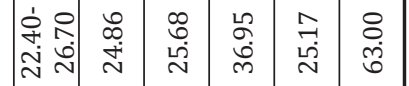

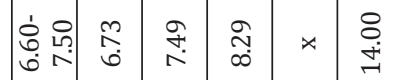

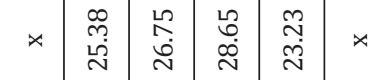

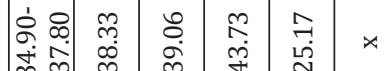

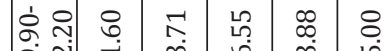
خें $\dot{m}$ ले

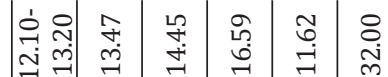
iे \& \& ๗ं

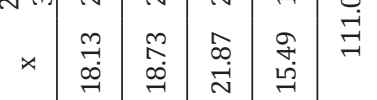
b่:

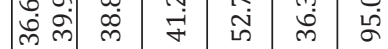

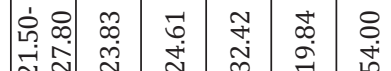

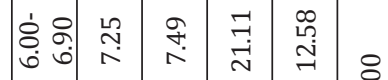

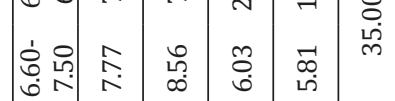

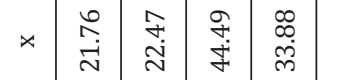

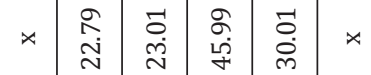

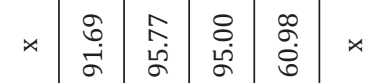

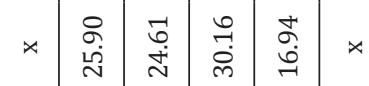

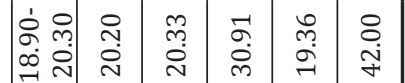

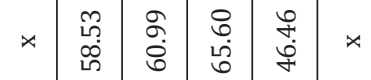

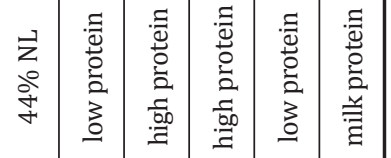

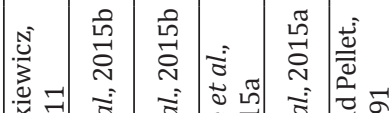

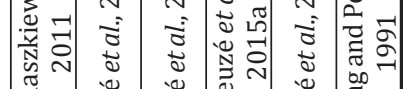

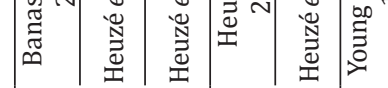

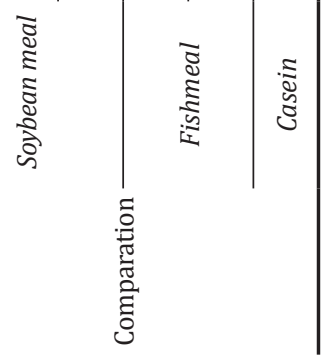




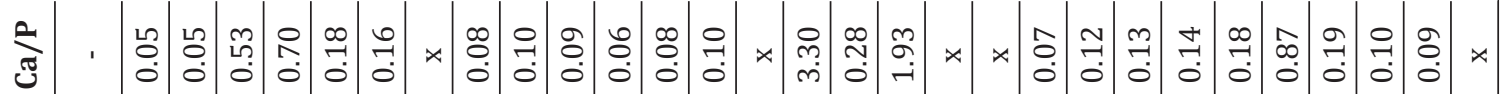

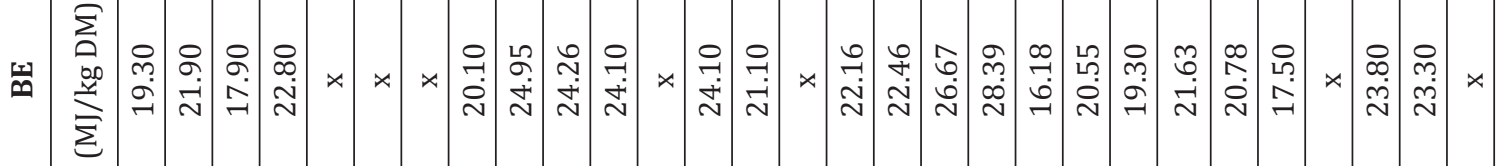

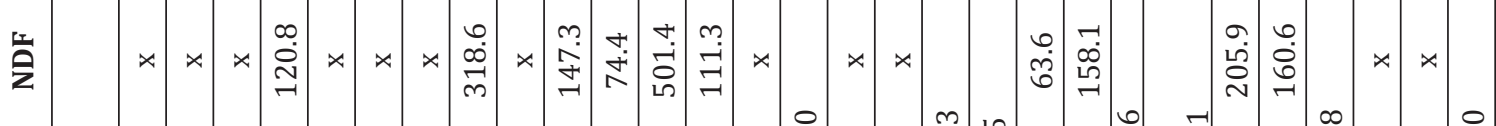

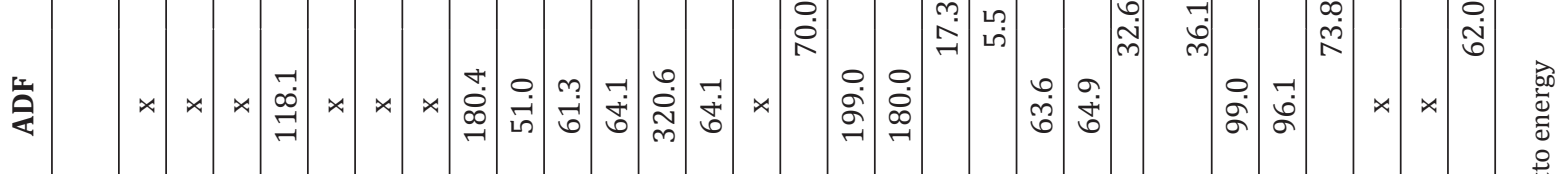

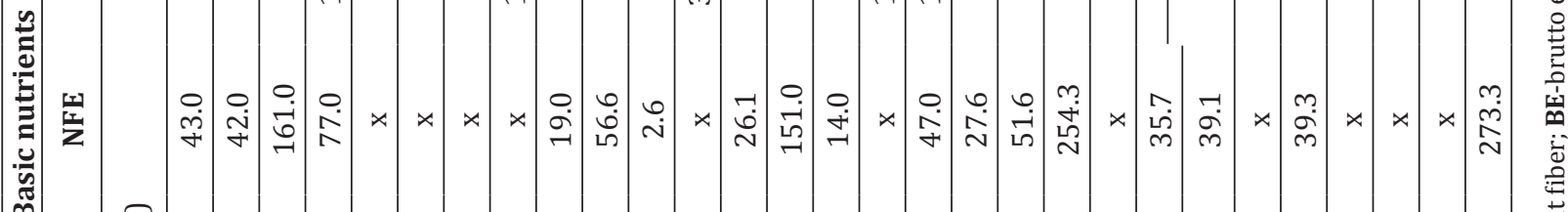

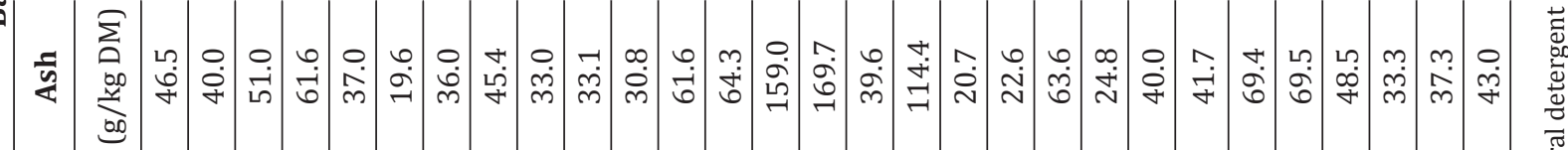

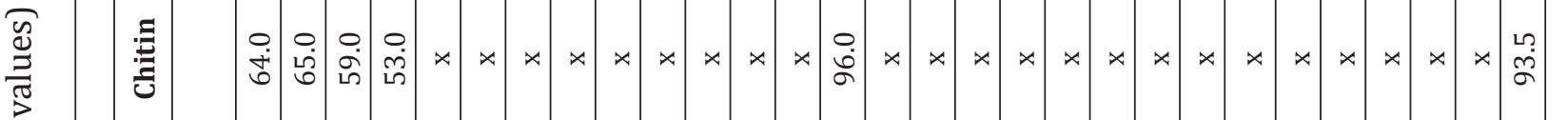

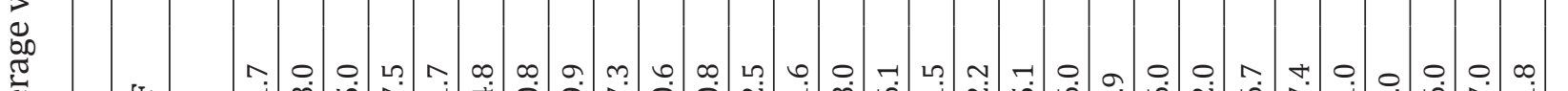

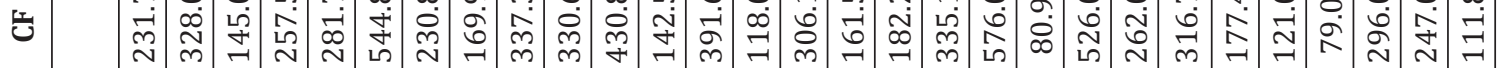

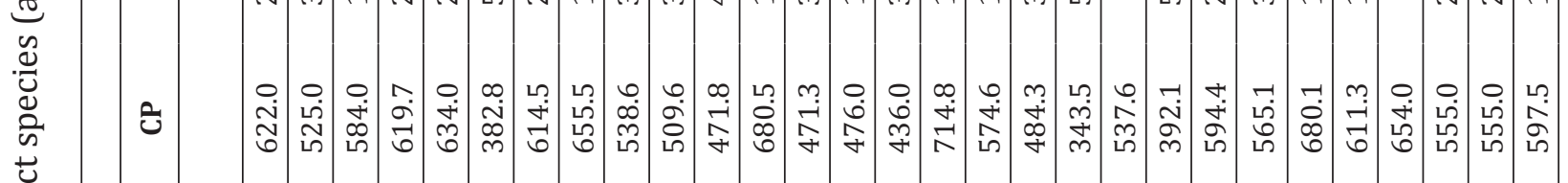

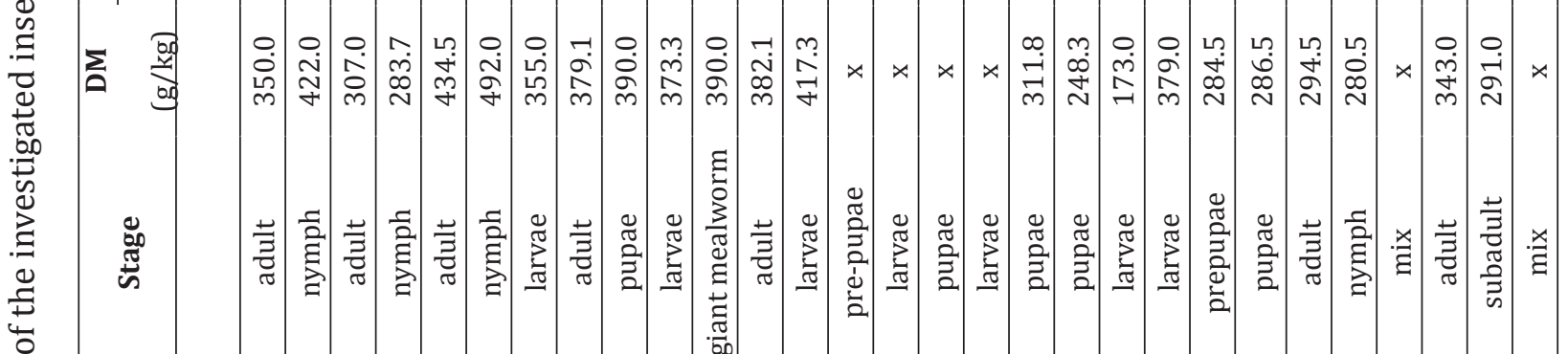

营

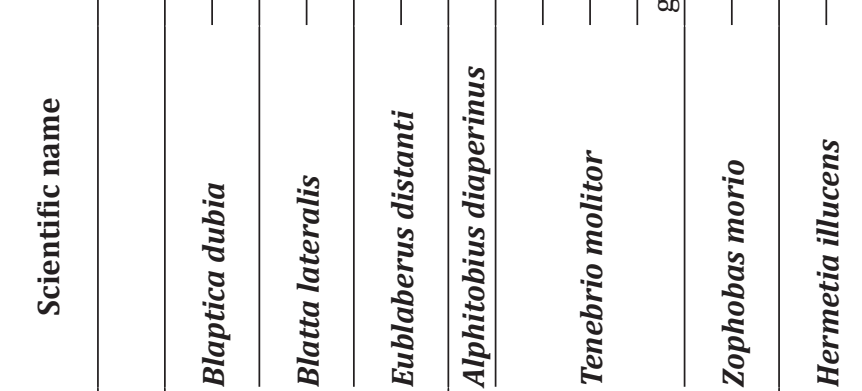

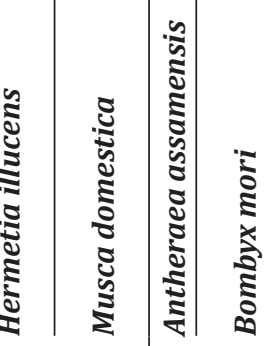

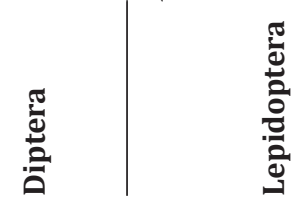

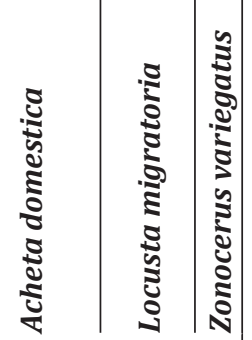

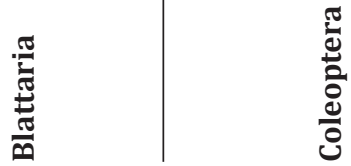

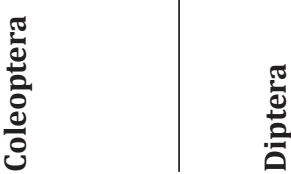

 


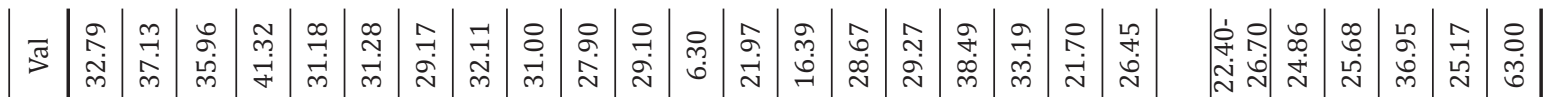

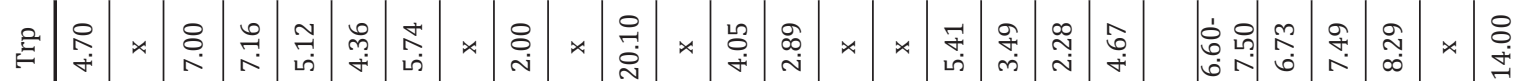

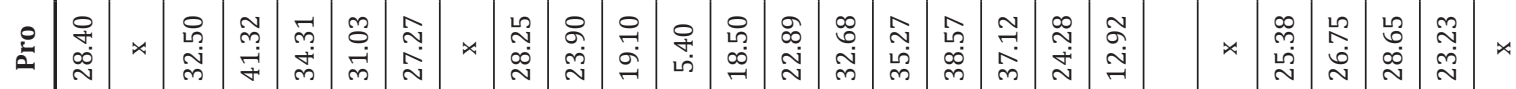
我

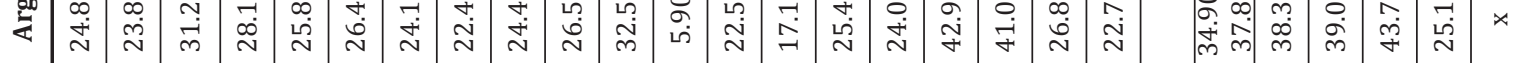

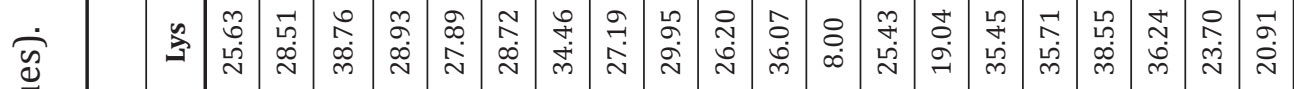

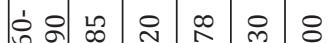

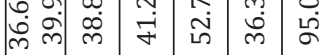

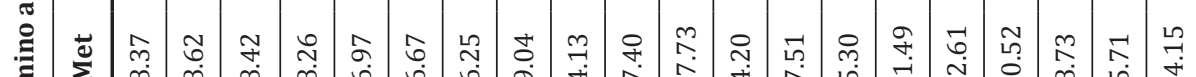

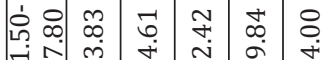

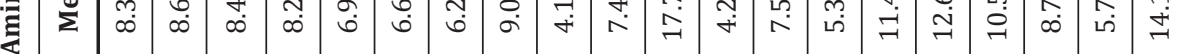

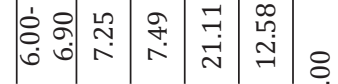

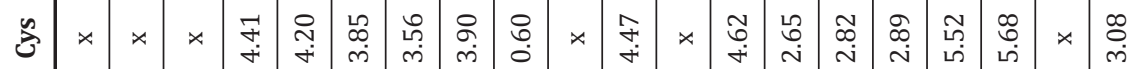

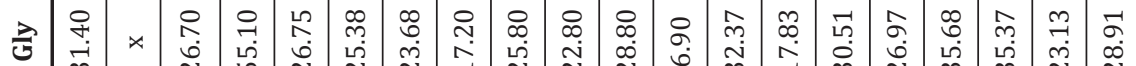

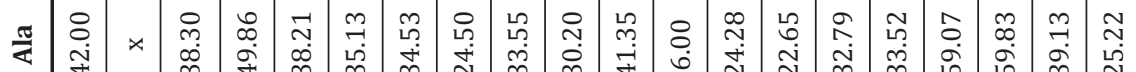

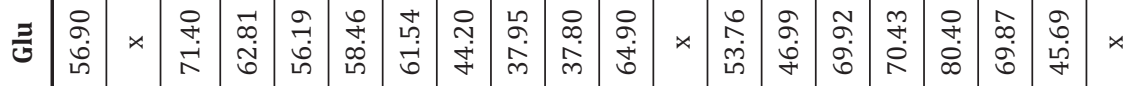

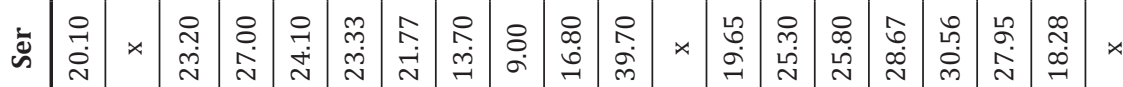

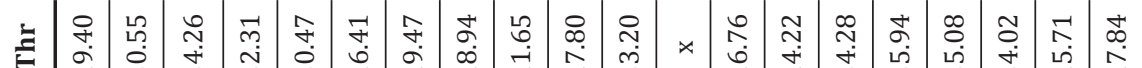

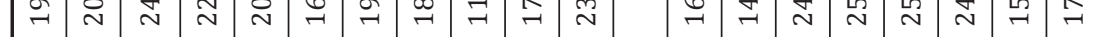

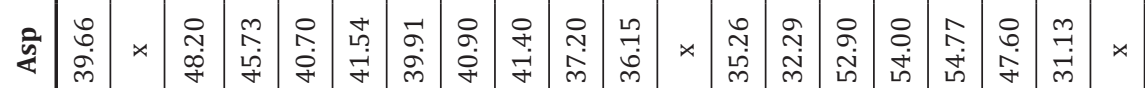

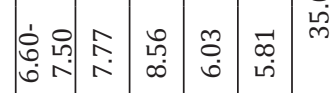

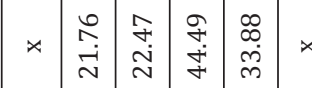

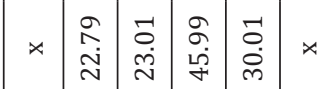

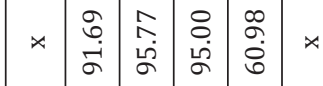

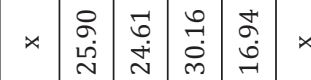
离

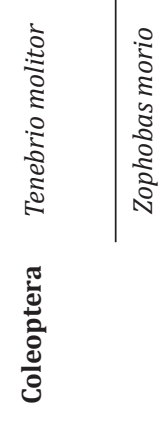

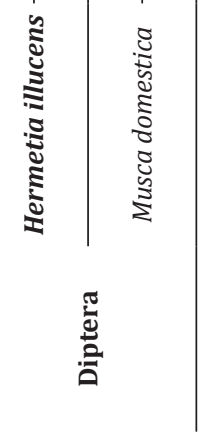
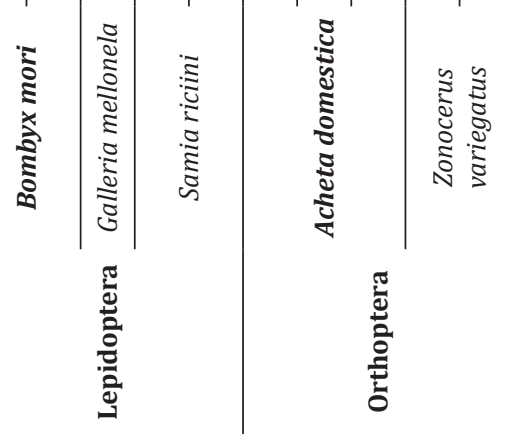

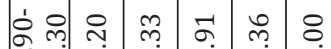
$\rightarrow$ i

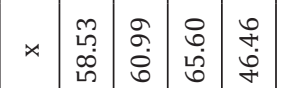

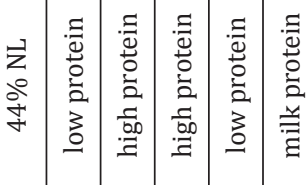

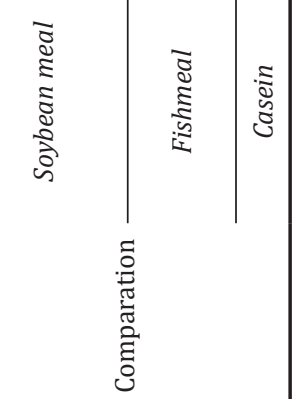


similar to that of conventional commercial protein sources - fishmeal and soybean meal. In terms of protein quality, it was found that insect protein composition is more similar to soybean protein or fishmeal with low protein concentration, than to that of high concentration fishmeal or casein.

Although many authors deal with this topic, complete information about the nutritional value of the reviewed species is rather unavailable. Despite the fact that the basic nutritional composition of most species is well known (see Table 1), the information about quality of their proteins (see Table 2) and lipids (see Table 3) is unfortunately insufficient. Detailed chemical analyses of other insect species are also available, but those specimens have been obtained from nature (by collecting, etc.), which means we do not consider them as suitable for mass production (Adeyeye and Awokunmi, 2010; Wang et al., 2005).

Breeders of insectivorous companion animals rear many more insect species, especially to improve the animals' diet, but also as a kind of enrichment. Due to the high cost of inputs, the price of small scale reared insects is several times higher than it is supposed to be in mass production. Therefore, developing technologies for rearing intensification purposes is essential.

Based on available data, the nutritional value of the insects varied among individual orders, species and developmental stages. The available information indicates that the amount of nutrients could also vary according to the breeding methodology (e.g. diet composition, temperature, gut loading, etc.). There were instances where the published results for the same species differed substantially (e.g. Ca/P ratio in M. domestica by Bernard et al., 1997 and Djordjević et al., 2008).

Regarding Table 1 , the protein content of most of the reviewed insect species ranged between 339.8 $799.1 \mathrm{~g} / \mathrm{kg} \mathrm{DM}$, which could be considered as similar to or slightly higher than in soybean $(438-535 \mathrm{~g} /$ $\mathrm{kg}$ DM) and fish meals (484.0 - $754.0 \mathrm{~g} / \mathrm{kg} \mathrm{DM}$ ). The exception for this criterion (i.e. crude protein content lower than $438 \mathrm{~g} / \mathrm{kg}$ ) were two species of the Lepidoptera order - G. mellonela larvae, B. mori pupae; one Diptera species - $H$. illucens larvae, and nymphs of $E$. distanti, Blattaria. On the other hand, the average protein contents of adult $A$. domestica or pupae of $M$. domestica were almost equal to that of high concentration fishmeals.
Most farm animal requirements are not specified in protein quantity, but in its quality. Knowledge of amino acid composition is therefore necessary. In terms of animal feeding, the most important aspect is the content of limiting amino acids. The most frequent farm animal species associated with using insect meal as an alternative protein source are pigs (Adeniji, 2008; Coll et al., 1992) and poultry (Ramos-Elorduy, 2002; Tas, 1985; Téguia et al., 2002).

The limiting amino acid in pig nutrition is lysin (Subcommittee on Swine Nutrition et al., 1979). As shown in Table 5., the average lysin content in insects has been found to be significantly lower than in casein or high protein fishmeals, but similar to that of soybean meal (12 groups) or low protein fishmeal (7 groups). The lowest level ( $8 \mathrm{~g} / \mathrm{kg} \mathrm{DM})$ of lysin was found in B. mori pupae. The average level of methionin (see Table 5) which is limiting amino acid in poultry nutrition (Subcommittee on Poultry Nutrition et al., 1994), in most insects was similar to or slightly higher than in soybean meal. Only 3 species (M. domestica larvae, S. riciini pupae and a stadium mix of $Z$. variegatus) had the same methionin content as low protein fishmeal. None of the reviewed species neared methionin values of high protein fishmeals or milk protein. The same situation occurred with almost all essential amino acids (see Table 3 and Table 5), except leucin. Average leucin level was unexpectedly higher in both nymphs and adults of $A$. domestica than in high protein fishmeal.

The insects also contain high levels of lipids (see Table 1), ranging from 66.6 to $600.0 \mathrm{~g} / \mathrm{kg} \mathrm{DM}$. These contents are several times higher than that of soybean meal and fishmeal. The lowest average lipid levels were found in two Orthoptera species: $Z$. variegatus and $A$. domestica, which both may be considered similar to fishmeal in terms of fat content. The highest average lipid levels have been conversely found in Lepidoptera species B. mori (pupae) and G. mellonela. Both these groups were actually the only investigated insects with higher lipid than protein content. The quality of lipids is expressed by fatty acid composition. Unfortunately, the information about that is limited (see Table 2 ), but it is known that fatty acid composition is influenced by its composition in the insect's diet (Stanley-Samuelson et al., 2005), so we assume that these values may vary greatly. 
An anti-nutritional factor contained in the insects is polysaccharide chitin. Information about its content in insects is very limited, but the available results indicate that it reaches levels many times higher than indigestible polysaccharide lignin levels contained in soybean meals.

The gross energy (see Table 1) content was $11.5-29.6 \mathrm{MJ} / \mathrm{kg} \mathrm{DM}$, most of the investigated groups (10) exhibiting higher average energy content than both fishmeal and soybean meal. On the other hand, seven groups of insect containing slightly lower energy amount have also been found.

The ash content (see Table 1) in insects was found in a large variety of $11.1-240.0 \mathrm{~g} / \mathrm{kg} \mathrm{DM}$. Except for a few Diptera species, the reviewed insects contained similar amounts of ash as there is in soybeanmeal. However, the ratio of the most important macroelements $\mathrm{Ca}: \mathrm{P}$ is generally significantly lower than in fishmeal and soybean meal. The only investigated groups containing more calcium than phosphorus were the maggots of two Diptera species.

The studied insects expectedly contained low levels of NFE (see Table 1), probably formed only by feed residues. Only three exceptions with NFE content higher than $100 \mathrm{~g} / \mathrm{kg}$ DM were found in sources - adult B. lateralis (Kulma et al., in prep), H. illucens (Kroeckel et al., 2012) and B. mori (Finke, 2002). On the other hand, negative values have been reported by Finke (2002) as well.

\section{CONCLUSION}

The collected data indicate that insect meals could be considered as a potential future substitute for currently used protein sources in agriculture. Further research including more aspects (mass production, economy, rearing techniques, possibilities of nutrient content manipulation, etc.) of using insect meals is undoubtedly needed.

Based on the highest lysin and methionin content, we propose Musca domestica larvae and Samia ricini as the best alternatives to commonly used protein sources for poultry and pig feeding.

Acknowledgements: this work was partly supported by the Internal Grant Agency of the Czech University of Life Sciences Prague (CIGA) through project No. 20152004.

\section{REFERENCES}

7. Adeniji AA (2008). The feeding value of rumen contentmaggot meal mixture in the diets of early weaned piglets. Asian J. Anim. Vet. Adv. 3: 115-119.

8. Adeyeye EI, Awokunmi EE (2010). Chemical composition of female and male Giant African Crickets, Brachytrypes membranaceus. International Journal of Pharma and Bio Sciences. 1: 125-136.

9. Alegbeleye WO, Obasa SO, Olude OO, Otubu K, Jimoh W (2012). Preliminary evaluation of the nutritive value of the variegated grasshopper (Zonocerus variegatus L) for African catfish Claria gariepinus (Burchell, 1822) fingerlings.Aquacult. res. 43: 412-420.

10. Aniebo AO, Owen OJ (2010). Effects of age and methodof drying on the proximate composition of housefly larvae (Musca domestica Linnaeus) meal (HFLM). Pak. J. Nut. 9: 485-487.

11. Arango Gutierrez GP, Vergara Ruiz RA, Mejia Velez H (2004). Compositional, microbiological and protein digestibility analysis of larval meal of Hermetia illucens (Diptera: Stratiomyidae) at Angelopolis-Antioquia, Colombia. Rev. Facult. Nacl. Agron. Med. 57: 2491-2499.

12. Barker D, Fitzpatrick MP, Dierenfeld ES (1998). Nutrient composition of selected whole invertebrates. Zoo. Biol. 17: 123-134.

13. Banaskiewicz T (2011). Nutritional value of Soybean meal. Pp. 1-20. In: El-Shemy, H. (ed.). Soybean and Nutrition. In Tech, Rijeka, 476 pp. Available from: http:// www.intechopen.com/books/soybean-andnutrition/ nutritional-value-of-soybean-meal

14. Bernard JB, Allen ME, Ullrey DE (1997). Feeding Captive Insectivorours Animals Nutritional aspects of Insects as Food. Nutrition Advisory group. Handbook. Fact sheet 003. Scientific Advisory Group to the American Zoo and Aquarium Association.

15. Bosch G, Zhang S, Oonincx DGAB, Hendriks WH (2014). Protein quality of insects as potential ingredients for dog and cat foods. Journal of Nutritional Science. 3(e29): 1-4.

16. Coll JFC, Crespi MPAL, Itagiba MGOR, Souza JCD, Gomes AVC, Donatti FC, (1992). Utilization of silkworm pupae meal (Bombyx mori L.) as a sourceof protein in the diet of growing-finishing pigs. Rev. Soc. Bras. Zootec. 21, 378383.

17. Deori M, Devi D, Devi R (2014). Nutrient Composition and Antioxidant Activities of Muga and Eri Silkworm Pupae. Int. Journ. Sci. Nat. 5(4): 636-640.

18. Deydier E, Guilet R, Sarda S, Sharrock P (2005). Physical and chemical characterisation of crude meat and bone meal combustion residue: "waste or raw material?". Journal of Hazardous Materials. 121: 141 - 148

19. Djordjevic M, Radenkovic-Damnjanovic B, Vucinic M, Baltic M, Teodorovic R, Jankovic L, Vukasinovic M, Rajkovic $\mathrm{M}$ (2008). Effects of substitution of fis meal with fresh and dehydrated larvae of the house fly (Musca domestica $\mathrm{L}$ ) on productive performance and health of broilers. Acta Vet serbia. 58: 357-368.

20. Finke M D (2002). Complete nutrient composition of commercially raised invertebrates used as food for insectivores. Zoo. Biol. 21: 269-285.

21. Heuzé V, Tran G, Kaushik S (2015a). Fish meal. Feedipedia, a programme by INRA, CIRAD, AFZ and FAO. http://www. feedipedia.org/node/208. Last updated on May 11, 2015, $14: 32$ 
22. Heuzé V, Tran G, Kaushik S (2015b). Soybean meal. Feedipedia, a programme by INRA, CIRAD, AFZ and FAO. http://www.feedipedia.org/node/674 Last updated on May 19, 2015, 15:44

23. Hwangbo J, Hong EC, Jang A, Kang HK, Oh JS, Kim BW, Park BS (2009). Utilization of house fly-maggots, a feed supplement in the production of broiler chickens. Journal of Environmental Biology. 30(4): 609-614.

24. Katayama N, Ishikawa Y, Takaoki M, Yamashita M, Nakayama S, Kiguchi K, Kok R, Wada H, Mitsuhashi J (2008). Entomophagy: a key to space agriculture. Adv. Space. Res. 41: 701-705.

25. Kroeckel S, Harjes AGE, Roth L, Katz H, Wuertz S, Susenbeth A, Schulz C (2012). When a turbot catches a fly evaluation of a pre-pupae meal of the Black Soldier Fly (Hermetia illucens) as fish meal substitute - growth performance and chitin degradation in juvenile turbot (Psetta maxima) Aquaculture. 364-365: 345-352.

26. Kulma M, Plachý V, Vrabec V, Bubová T, Orsák M in prep. Nutritional composition differences between three species of subadult and adult cockroaches.

27. Longvah T, Mangthya K, Ramulu P (2011). Nutrient composition and protein quality evaluation of eri silkworm (Samia ricinii) prepupae and pupae. Food. Chem. 128: 400-403.

28. Makkar H P S, Tran G, Heuzé V, Ankers P (2014). State of the art on use of insects as animal feed. Anim. Feed Sci. Technol. 197: 1-33.

29. Mishra N, Hazarika NC, Narain K, Mahanta J (2003). Nutritive value of non-mulberry and mulberry silkworm pupae and consumption pattern in Assam, India. Nutr. Res. 23: 1303-1311.

30. Nagasaki BJ, DeFoliart GR (1987). Protein quality of the house cricket Acheta domesticus when fed to rooster chicks. Poult. Sci. 66: 1367-1371.

31. Newton GL, Booram CV, Barker RV, Hale OM (1977). Dried Hermetia illucens larvae meal as a supplement for swine. J. Anim. Sci. 44: 395-400

32. Ogunji JO, Nimptsch J, Wiegand C, Schulz C 2007. Evaluation of the influence of housefly maggot meal (magmeal) diets on catalase, glutathione S-transferase and glycogen concentration in the liver of Oreochromis niloticus fingerling. Comp. Biochem. Physiol. 147: 942947.

33. Olusola L, Solomon M, Maduka H (2003). Proximate Chemical Analysis of Zonocerus veriegatus (Giant Grasshopper). Nig. J. of Biotech. 14: 42-45.

34. Oonincx DGAB, van der Poel AFB (2011). Effects of Diet on the Chemical Composition of Migratory Locusts (Locusta migratoria). Zoo. Biol. 30: 9-16.

35. Oonincx D, Dierenfeld E (2012). An investigation into the chemical composition of alternative invertebrate prey. Zoo. Biol. 31: 40-54.

36. Pretorius Q (2011). The Evaluation of Larvae of Musca domestica (Common House Fly) as Protein Source for Broiler Production. M.Sc. Thesis. University of Stellenbosch.

37. Ramos-Elorduy J, Avila Gonzalez E, Rocha Hernandez A, Pino JM (2002). Use of Tenebrio molitor (Coleoptera: Tenebrionidae) to recycle organic wastesand as feed for broiler chickens. J. Econ. Entomol. 95: 214-220.
38. Ramos-Elorduy J, Medeiros-Costa E, Ferreira-Santos J, Pino-Moreno JM, Landero-Torres L, Angeles-Campos SC, García- Pérez A (2006). Estudio comparativodel valor nurritivo de varios coleopteran comestibles de México y Pachymerus nucleorum (Fabricius, 1792) (Bruchidae) de Brasil. Interciencia. 31: 512-516.

39. Rumpold BA, Schlüter OK (2013). Potential and challenges of insects as an innovative source for food and feed production. Innovative Food Science and Emerging Technologies. 17: $11-13$.

40. Sánchez- Muñoz MJ, Barroso FG, Manzano-Agugliaro $F(2014)$. Insect meal as renewable source of food for animal feeding: a review. Journal of Cleaner Production. 65: 16-27.

41. Sealey WM, Gaylord TG, Barrows FT, Tomberlin JK, McGuire MA, Ross C, St-Hilaire S (2011). Sensory analysis of rainbow trout Oncorhynchus mylass, fed enriched black soldier fly prepupae, Hermetia illucens. J. World Aquacult. Soc. 42 : 34-45.

42. Stanley-Samuelson DW, Jurenka RA, Cripps C, Blomquist GJ, de Renobales M (2005). Fatty acids in insects: Composition, metabolism, and biological significance. Archives of Insect Biochemistry and Physiology. 9: 1-33.

43. St-Hilaire S, Sheppard C, Tomberlin JK, Irving S, Newton L, McGuire MA, Mosley EE, Hardy RW, Sealey W (2007). Fly Prepupae as a Feedstuff for Rainbow Trout, Oncorhynchus mykiss. Jour. World Aquacult. Soc. 38(1): 59-67.

44. Subcommittee on Poultry Nutrition, Committee on Animal Nutrition, Board on Agriculture, National Research Council (1994). Nutrient Requirements of Poultry: Ninth Revised Edition. National Academy of Sciences, Washington, D. C., 157 pp. Available from the National Academies Press at: http://www.nap.edu/catalog/2114.html

45. Subcommittee on Swine Nutrition; Committee on Animal, Nutrition; Board on Agriculture and Renewable Resources; National Research Council (1979). Nutrient Requirements of Swine: Eighth revised edition. National Academy of Sciences, Washington, D. C., 52 pp. Available from The National Academies Press at http://www.nap. edu/catalog.php?record_id=19882

46. Tas A (1985). The Use of Silkworm Pupae to Replace Fish Meal or Meat and Bone Meal in Broiler Rations, Istanbul Universitesi Veteriner Fakültesi Dergisi. 9(1983): 65-77.

47. Téguia A, Mpoame M, Okourou Mba JA (2002). The production performance of broiler birds as affected by the replacement of fish meal by maggot meal in the starter and finisher diets. Tropicu. 20: 187-192.

48. Wang D, Zhai SW, Zhang CX, Bai YY, An SH, Xu YN. (2005). Evaluation on nutritional value of field crickets as a poultry feedstuff. Asian-aust. J. anim. Sci. 18: 667-670.

49. Yi L, Lakemond CM, Sagis LM, Eisner-Schadler V, van Huis A, van Boekel MA (2013). Extraction and characterisation of protein fractions from five insect species. Food Chem. 141: 3341-3348.

50. Zuidhof MJ, Molnar CL, Morley FM, Wray TL, Robinson FE, Khan BA, Al-Ani L, Goonewardene LA (2003). Nutritive value of house fly (Musca domestica) larvae as a feed supplement for turkey poults. Anim. Feed Sci. Technol. 105: 225-230. 